УДК 614.843

\title{
РЕЗУЛЬТАТИ АНАЛІЗУ ОСНОВНИХ ПОКАЗНИКІВ СТАТИСТИКИ ПОЖЕЖ В УКРАЇНІ ПО ВІДНОШЕННЮ ДО ЧАСУ ПРИБУТТЯ ПЕРШОГО ПІДРОЗДІЛУ ПОЖЕЖНОЇ ОХОРОНИ
}

Р.В. Климась, А.В. Одинець, Д.Я. Матвійчук, Л.П. Несенюк

Український науково-дослідний інститут цивільного захисту, Україна

\section{ІНФОРМАЦІЯ ПРО СТАТТЮ}

Надійшла до редакції: 31.05 .2019

Пройшла рецензування: 25.06.2019

\section{КЛЮЧОВІ СЛОВА:}

статистичний облік пожеж, аналітичні матеріали, стан із пожежами, кількість пожеж, кількість загиблих унаслідок пожеж, кількість травмованих на пожежах, кількість врятованих на пожежах, нормативний час прибуття до місця пожежі, час прибуття до місця пожежі, абсолютні показники, відносні показники, пожежно-рятувальні підрозділи, динаміка загальної кількості, динаміка питомої ваги

\begin{abstract}
АНОТАЦІЯ
Проаналізовано основні показники статистики пожеж в Україні, як в цілому, так і у містах та сільській місцевості України окремо, за нормативним часом прибуття першого підрозділу пожежної охорони до місця виклику за довгостроковий період.
\end{abstract}

Постановка проблеми. Облік пожеж та їх наслідків - в Україні ведеться згідно 3 нормативними документами $\left[\begin{array}{lll}1, & 2,3\end{array}\right]$. Критеріями, за якими утворюються державні пожежно-рятувальні підрозділи (далі - ПРП) в адміністративно-територіальних одиницях [4], $€$ : кількість жителів населеного пункту; радіус обслуговування одним ПРП; нормативи прибуття ПРП до місця виклику.

Останні дослідження Міжнародної асоціації пожежно-рятувальних служб (далі CTIF) [5] спонукають до визначення тенденцій у сфері забезпечення захисту населення в нашій державі, виявлення суперечностей в оцінюванні в цілому роботи існуючої системи реагування на небезпечні події в Україні.

Основними проблемами реагування на небезпечні події, пов'язані з пожежами, є:

- необхідність реформування місцевого самоврядування, передача низки функцій від держави до місцевих органів влади, збільшення кількості ПРП у сільській місцевості;

- протиріччя між пожежною технікою, для якої були розроблені існуючі керівні документи, та сучасною технікою, що надходить на озброєння пожежно-рятувальних підрозділів;

- низький рівень підготовленості особового складу ПРП щодо виконання поставлених перед ним завдань.
Вирішення цих проблем підвищить рівень реагування ПРП на пожежі, зокрема дозволить зменшити час прибуття ПРП на пожежу.

Аналіз останніх досліджень та публікацій. В статті [6] Красавін А. В. наводить свою точку зору, що оптимізація дислокації пожежних депо передбачає врахування численних, у тому числі самих дрібних, деталей і нюансів, що впливають на час оперативного реагування пожежних i ïx прибуття до будь-якого об'єкту. Аналізує нормативні документи щодо вимог, які ставляться до часу прибуття пожежних підрозділів. Висловлює думку, що для досягнення нормативного часу прибуття до місця пожежі не обов'язково будувати нові депо, а укомплектовувати старі новітньою технікою. Також, використовуючи загальновизнані наукові досягнення, що оптимізують дислокацію підрозділів пожежної охорони, можна бути впевненим, що прийнята дислокація забезпечить мінімальний час прибуття пожежних підрозділів до місця виклику.

У статті [7] Матюшин А. В. наводить два підходи щодо визначення швидкості слідування підрозділів пожежної охорони на місце пожежі, перший $з$ яких заснований на аналізі статистичної інформації за виїздами підрозділів пожежної охорони на виклик за певний проміжок часу, в основі другого підходу лежить експериментальний метод. Дані про швидкість руху пожежних

*E-mail: matviichuk_d@dsns.gov.ua 
автомобілів отримують шляхом вимірювання швидкостей їх руху по ділянках транспортної мережі населеного пункту в певні проміжки часу.

У своїй статті Титаренко А. В. [8] стверджує, що час прямування підрозділів на виклик $є$ складовою частиною показника часу реагування, від якого майже лінійно залежать розміри матеріальних збитків і ймовірність загибелі та травмування людей у результаті дії на них небезпечних чинників пожежі. Він залежить від часу збору, виїзду та прямування до місця виклику.

У процесі реалізації Стратегії реформування системи Державної служби України з надзвичайних ситуацій проводиться поступове оновлення автопарку основних автомобілів. Однак, за результатами проведених досліджень в своїй статті Белюченко Д. Ю. та Стрілець В. М. [9] стверджують, що ефективність проведення оперативної роботи особовим складом супроводжується протиріччям між пожежною технікою, для якої були розроблені існуючі керівні документи та сучасною технікою, що поступає на озброєння ПРП. А час оперативного розгортання для однотипних варіантів відрізняється від рівня підготовленості особового складу.

3 метою вивчення проблеми підготовки керівного складу ПРП на основі аналізу їх оперативних дій за напрямком реагування Войтович Д. П. [10] висловив думку, що для підвищення оперативної роботи необхідно внести в навчальні програми професійноорієнтованих дисциплін («пожежна тактика», «організація аварійно-рятувальних робіт») тематики, що пов'язані із вивченням питань аналізу дій підрозділів оперативнорятувальної служби цивільного захисту за призначенням.

Групою авторів під головуванням Брушлинського В. В. [11] було проаналізовано показники статистик пожеж на прикладі міста Москви, виявлено i досліджено фактори впливу на них, що дозволило розробити алгоритм управління пожежною безпекою, сформулювати пропозиції загального характеру для протипожежного захисту міст, регіонів та держави, зокрема для державної протипожежної служби, підвищення оперативної роботи шляхом зменшення часу прибуття до місця пожежі.

Відповідно до [12] у Російській Федерації розроблені методичні рекомендації, що призначені для визначення меж територій міських населених пунктів і сільських районів, у межах яких час прибуття першого підрозділу пожежної охорони відповідає нормативним значенням.

Мета даної роботи полягала в аналізі основних показників статистики пожеж в Україні, як в цілому, так і у містах і сільській місцевості України окремо, по відношенню до часу прибуття першого пожежнорятувального підрозділу до місця виклику за довгостроковий період та надання пропозицій щодо удосконалення системи реагування на небезпечні події, пов'язані 3 пожежами, в Україні.

Виклад основного матеріалу. Аналіз основних показників статистики пожеж за часом прибуття першого підрозділу пожежної охорони на пожежу виконувався за допомогою аналітичних методів досліджень шляхом збирання, узагальнення, оброблення й аналізування статистичних даних про пожежі та наслідки від них в Україні, а також інформації, що міститься в нормативноправових актах і нормативних документах, щодо реагування на небезпечні події, пов'язані 3 пожежами; формування масивів статистичних даних проводилося методами приєднання даних, зв'язування даних, злиття даних; оброблювання первинних даних про пожежі виконувалося за допомогою методів математичної статистики (масового спостереження, статистичного аналізу, регресії, статистичного зведення та групування, статистичної обробки зведених i розгрупованих показників, статистичного розподілу, максимальної вірогідності).

У роботі проаналізовано статистичні дані про пожежі в Україні щодо показників реагування на них пожежно-рятувальних підрозділів за довгостроковий період та обгрунтовано шляхи вдосконалення ефективного реагування пожежнорятувальних підрозділів на небезпечні події, пов'язані з пожежами, в Україні.

Оцінювання останніх даних [5] спонукає до визначення тенденцій у сфері забезпечення захисту населення в Україні, виявлення суперечностей в оцінюванні в цілому роботи існуючої системи реагування на небезпечні події, пов'язані з пожежами, та удосконалення системи реагування на них. У таблиці 1 наведено дані щодо чисельності протипожежних служб в деяких країнахчленах CTIF за $2001 \div 2016$ роки. 
Таблиця 1 - Усереднені дані щодо чисельності протипожежних служб в деяких країнах членів CTIF за $2001 \div 2016$ роки

\begin{tabular}{|c|c|c|c|c|c|c|c|c|c|c|}
\hline \multirow[b]{2}{*}{ Країна } & \multirow{2}{*}{$\begin{array}{c}\text { Населе- } \\
\text { ння, } \\
\text { тис, ос. }\end{array}$} & \multirow[b]{2}{*}{$\begin{array}{c}\text { Площа, } \\
\text { км }^{2}\end{array}$} & \multirow{2}{*}{$\begin{array}{c}\text { Кількість } \\
\text { пожежних } \\
\text { депо }\end{array}$} & \multirow{2}{*}{\begin{tabular}{|c|} 
Площа \\
обслуго- \\
вування \\
одним \\
депо, \\
км² $^{2}$ \\
\end{tabular}} & \multirow{2}{*}{$\begin{array}{c}\text { Кількість } \\
\text { населення } \\
\text { на одне } \\
\text { депо, } \\
\text { тис. ос. }\end{array}$} & \multicolumn{2}{|c|}{ Кількість* } & \multicolumn{3}{|c|}{$\begin{array}{c}\text { Чисельність особового } \\
\text { складу }\end{array}$} \\
\hline & & & & & & $\begin{array}{c}\text { АЦ } \mathrm{i} \\
\mathrm{AH}\end{array}$ & $\begin{array}{l}\text { АД i } \\
\text { КП }\end{array}$ & $\begin{array}{l}\text { Профе- } \\
\text { сійного }\end{array}$ & $\begin{array}{c}\text { Добро- } \\
\text { вільного }\end{array}$ & Всього \\
\hline Франція & 66628 & 6 & 6528 & 99 & 10 & 7542 & 1195 & 40646 & 193800 & 234446 \\
\hline Україна & 42673 & 603628 & 968 & 624 & 44,1 & 3177 & 296 & 55241 & 156749 & 211990 \\
\hline Німеччина & 82218 & 357386 & 33460 & 11 & 2,5 & 41216 & 2414 & 31308 & 999688 & 1027996 \\
\hline Польща & 38454 & 312679 & 16805 & 19 & 2 , & 19800 & 722 & 29907 & 259519 & 289426 \\
\hline Італія & 61000 & 301338 & 902 & 334 & 67,6 & 2330 & 307 & 28870 & 20060 & 48930 \\
\hline Британія & 61370 & 242495 & 2053 & 118 & 29,9 & 2900 & 235 & 40100 & 1400 & 60500 \\
\hline
\end{tabular}

*АЦ - автоцистерна, АН - автонасос, АД - автодрабина, КП - колінчастий підйомник

Як бачимо, серед зазначених країн-членів CTIF, площа обслуговування одним пожежним

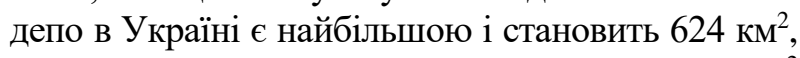
а кількість пожежної техніки на площу в 1 тис. км² - однією $з$ найменших і становить 6 одиниць. Кількість населення на території обслуговування одним депо становить 44,1 тисячу людей і $\epsilon$ однією з найбільших серед країн Європи.
У таблиці 2 наведено інформацію щодо усередненої кількості пожеж, загиблих унаслідок пожеж, травмованих на пожежах та врятованих на пожежах людей загалом та їх кількість і питома вага, на які прибували перші пожежно-рятувальні підрозділи за нормативним часом прибуття в містах та сільській місцевостях.

Таблиця 2 - Усереднена кількість основних показників пожеж за 2008 $\div 2017$ роки загалом та їх кількість і питома вага, на які прибували перші пожежно-рятувальні підрозділи за нормативним часом прибуття в містах та сільській місцевостях

\begin{tabular}{|c|c|c|c|c|c|c|}
\hline \multirow{2}{*}{ Показник } & \multicolumn{3}{|c|}{ Міста } & \multicolumn{3}{|c|}{ Сільська місцевість } \\
\cline { 2 - 7 } & $\begin{array}{c}\text { Усереднена } \\
\text { кількість }\end{array}$ & $\begin{array}{c}\text { Час прибуття } \\
\text { до 10 хв }\end{array}$ & $\%$ & $\begin{array}{c}\text { Усереднена } \\
\text { кількість }\end{array}$ & $\begin{array}{c}\text { Час прибуття } \\
\text { до 20 хв }\end{array}$ & $\%$ \\
\hline Пожеж, од & 39619 & 23202 & 58,6 & 25541 & 12444 & 48,7 \\
\hline Загиблих, людей & 1249 & 620 & 49,6 & 1341 & 387 & 28,9 \\
\hline $\begin{array}{c}\text { Травмованих } \\
\text { людей }\end{array}$ & 1043 & 580 & 55,6 & 494 & 175 & 35,4 \\
\hline $\begin{array}{c}\text { Врятованих, } \\
\text { людей }\end{array}$ & 2521 & 1880 & 74,6 & 353 & 192 & 54,3 \\
\hline
\end{tabular}

На рисунку 1 наведено динаміку питомої ваги пожеж у містах і сільській місцевості за нормативним часом прибуття пожежнорятувальних підрозділів.

За результатами досліджень статистичних даних за часом прибуття першого пожежнорятувального підрозділу до місця виклику спостерігається тенденція щодо збільшення питомої ваги кількості пожеж, на ліквідацію яких пожежно-рятувальні підрозділи прибували у нормований час. Разом із тим, питома вага пожеж у містах, на які час прибуття становив більше 10 хв, залишається високою $\mathrm{i}, \quad$ в середньому, становить понад $41 \%$. Питома вага пожеж, на ліквідацію яких підрозділи прибували у понаднормований час у сільській місцевості, у середньому складає понад $51 \%$.

На рисунку 2 наведено динаміку питомої ваги загиблих на пожежах у містах і сільській місцевості за нормативним часом прибуття пожежно-рятувальних підрозділів. 
口Питома вага пожеж у містах за часом прибуття до 10 хв, \%

口Питома вага пожеж у сільській місцевості за часом прибуття до 20 хв, \%

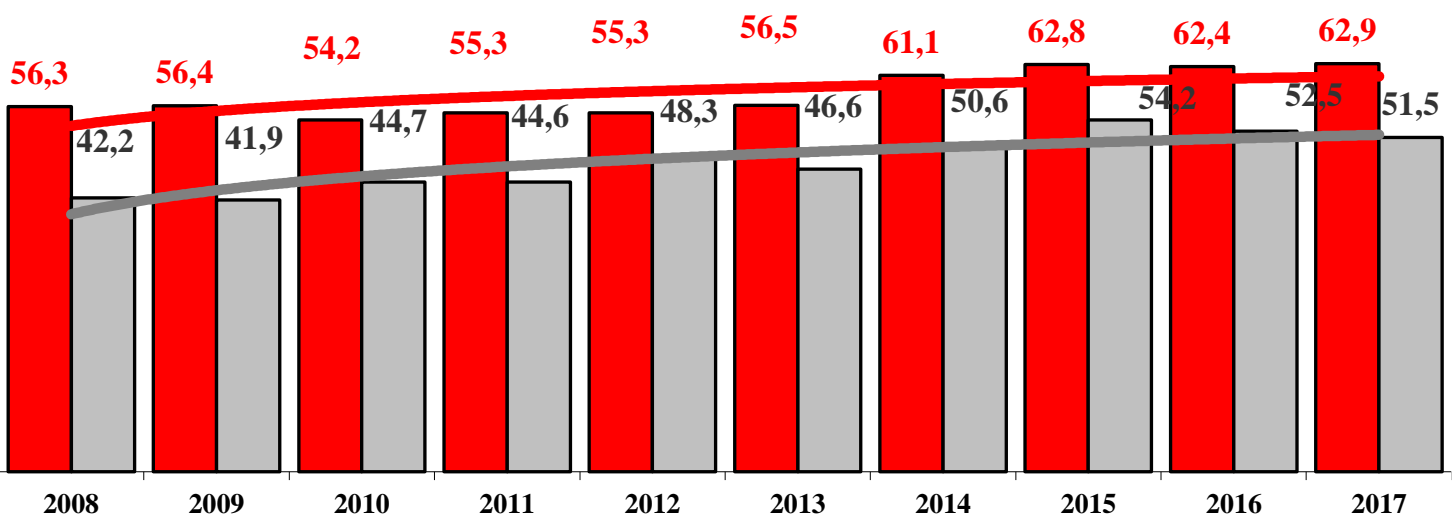

Рисунок 1 - Динаміка питомої ваги пожеж у містах і сільській місцевості за нормативним часом прибуття пожежно-рятувальних підрозділів

口 Питома вага загиблих у містах за часом прибуття до 10 хв, \%

口 Питома вага загиблих у сільській місцевості за часом прибуття до 20 хв, \%

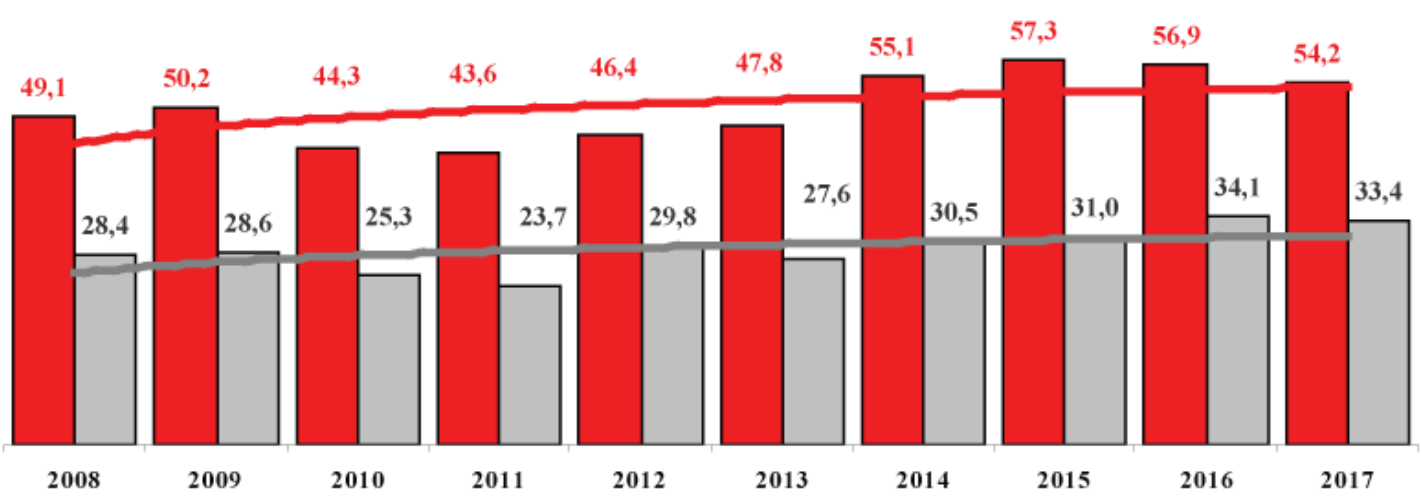

Рисунок 2 - Динаміка питомої ваги загиблих на пожежах у містах і сільській місцевості за нормативним часом прибуття пожежно-рятувальних підрозділів

За результатами досліджень статистичних даних за часом прибуття першого пожежнорятувального підрозділу до місця виклику спостерігається тенденція щодо зменшення питомої ваги загиблих на пожежах, на ліквідацію яких пожежно-рятувальні підрозділи прибували у нормований час. Разом із тим, питома вага загиблих на пожежах у містах, на які час прибуття становив більше 10 хв, залишається високою і в середньому становить понад $50 \%$. В сільській місцевості питома вага загиблих на пожежах, на ліквідацію яких підрозділи прибували у понаднормований час, у середньому, склала близько $71 \%$.

На рисунку 3 наведено динаміку питомої ваги травмованих на пожежах у містах та сільській місцевості за нормативним часом прибуття пожежно-рятувальних підрозділів. 
П Питома вага травмованих у містах за часом прибуття до 10 хв, \%

口 Питома вага травмованих у сільській місцевості за часом прибугтя до 20 хв, \%

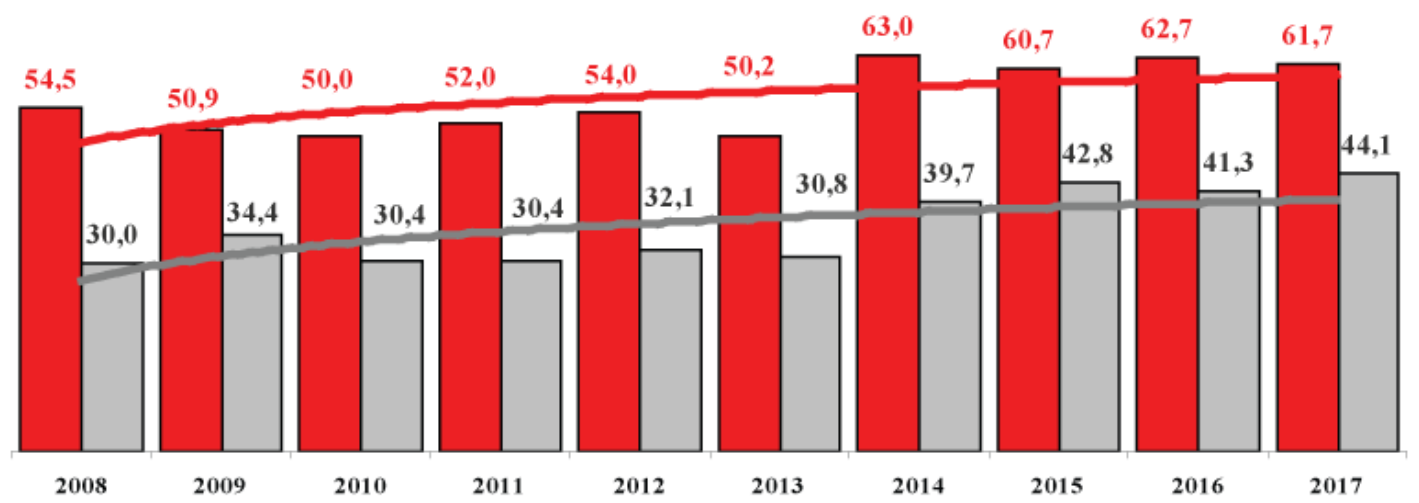

Рисунок 3 - Динаміка питомої ваги травмованих на пожежах у містах та сільській місцевості за нормативним часом прибуття пожежно-рятувальних підрозділів

За результатами досліджень статистичних даних за часом прибуття першого пожежнорятувального підрозділу до місця виклику спостерігається тенденція щодо незначного зменшення питомої ваги травмованих на пожежах, на ліквідацію яких пожежнорятувальні підрозділи прибували у нормований час. Разом із тим, питома вага травмованих на пожежах у містах, на які час прибуття становив більше 10 хв, залишається високою і в середньому становить понад $44 \%$. У сільській місцевості питома вага травмованих на пожежах, на ліквідацію яких підрозділи прибували у понаднормований час, $\mathrm{y}$ середньому, складає понад $64 \%$.

На рисунку 4 наведено динаміку питомої ваги врятованих на пожежах у містах та сільській місцевості за нормативним часом прибуття пожежно-рятувальних підрозділів.

口Питома вага врятованих у містах за часом прибуття до 10 хв, \%

口Питома вага врятованих у сільській місцевості за часом прибуття до 20 хв, \%

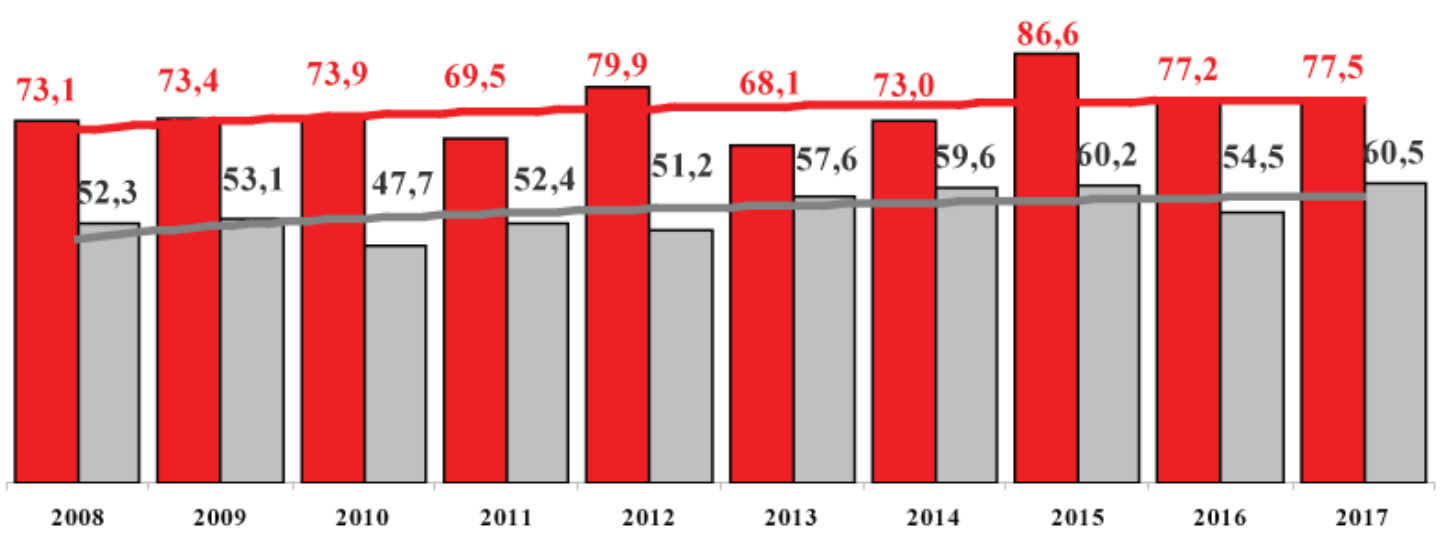

Рисунок 4 - Динаміка питомої ваги врятованих на пожежах у містах та сільській місцевості за нормативним часом прибуття пожежно-рятувальних підрозділів

За результатами досліджень статистичних даних за часом прибуття першого пожежнорятувального підрозділу до місця виклику спостерігається тенденція щодо незначного зменшення питомої ваги врятованих на пожежах, на ліквідацію яких пожежнорятувальні підрозділи прибували у нормований час. Питома вага врятованих на пожежах у містах, на які час прибуття становив більше 10 хв, у середньому становить понад 25\%. У сільській місцевості питома вага врятованих на пожежах, на ліквідацію яких підрозділи прибували у понаднормований час, у середньому, складає близько $46 \%$.

Динаміку середньої кількості пожеж i загиблих унаслідок пожеж за часом прибуття першого підрозділу на пожежу за $2008 \div 2017$ роки наведено на рисунку 5. 


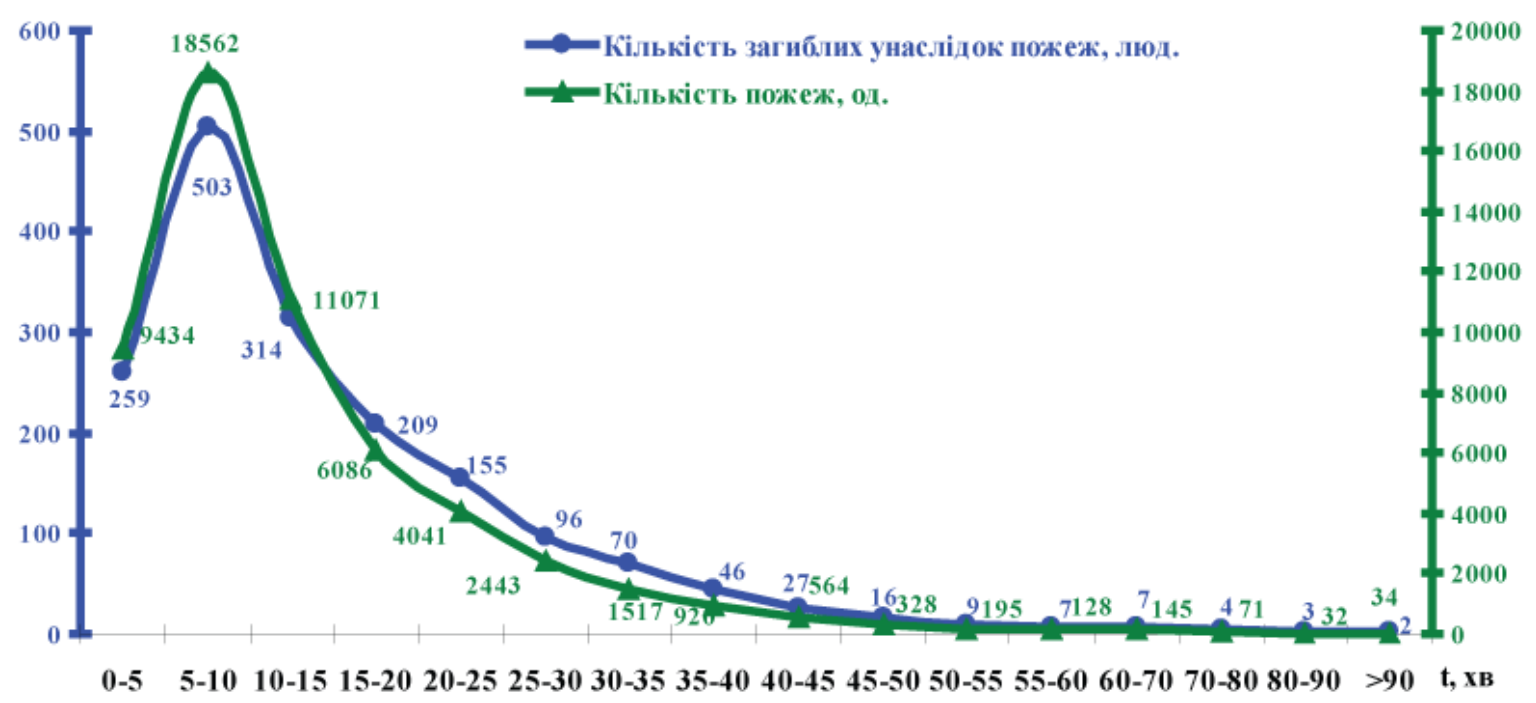

Рисунок 5 - Динаміка середньої кількості пожеж і загиблих унаслідок пожеж

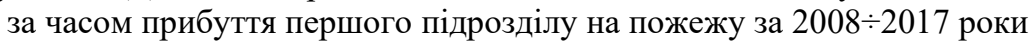

Як видно з рисунку 5, найбільша кількість людей гине на пожежах від п'ятої до десятої хвилини на момент прибуття першого підрозділу. В середньому, за десять років кількість людей, що загинули впродовж десяти хвилин на момент прибуття першого пожежно- рятувального підрозділу, становить 762 людини (44,2\% від загальної кількості загиблих).

На рисунку 6 наведено усереднений відносний показник кількості загиблих на 100 пожежах, за часом прибуття першого підрозділу на пожежу за $2008 \div 2017$ роки

Усереднений відносний показник кількості загиблих на 100 пожежах, за часом прибуття першого підрозділу на пожежу за 2008-2017 роки

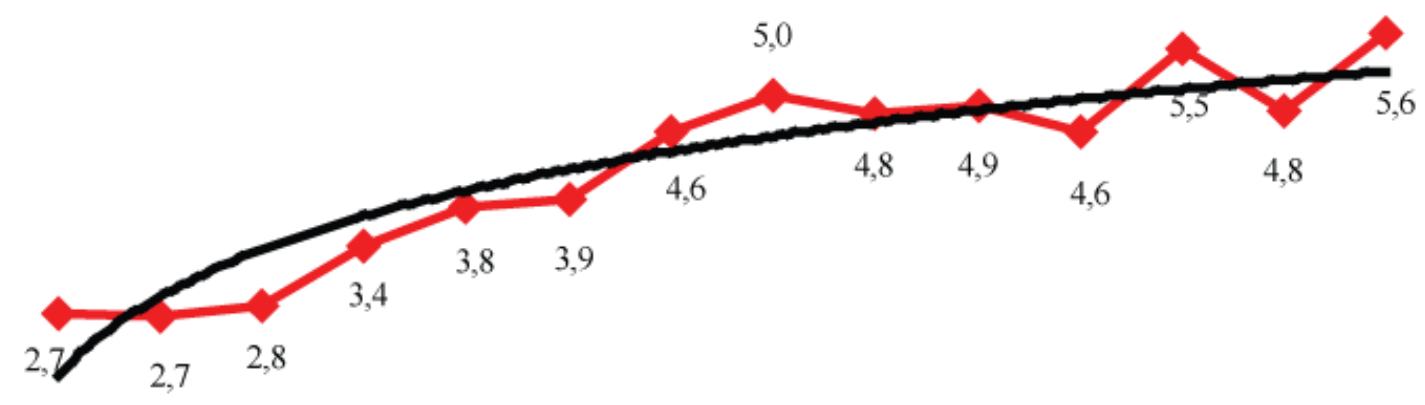

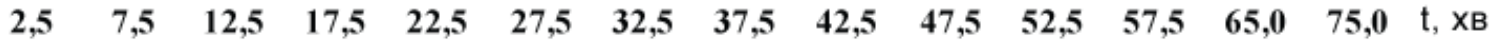

Рисунок 6 - Відносний показник кількості загиблих на 100 пожежах, за часом прибуття першого підрозділу на пожежу за $2008 \div 2017$ роки

Як видно з рисунку 6 відносний показник кількості загиблих людей на 100 пожеж за часом прибуття першого підрозділу до місця пожежі зростає до 37 хвилин розвитку пожежі, після чого залишається незмінним.
Результати аналізу основних показників статистики пожеж в Україні за нормативним часом прибуття першого підрозділу пожежної охорони на пожежу, вказують, що підвищення ефективності реагування на небезпечні події, пов'язані $з$ пожежами, потребує комплексного 
вирішення проблеми. Українським науководослідним інститутом цивільного захисту було надано пропозиції щодо удосконалення системи реагування на небезпечні події, пов'язані 3 пожежами, в Україні, а саме:

1.3 метою удосконалення системи реагування на небезпечні події, пов'язані 3 пожежами, зменшення кількості загиблих унаслідок пожеж людей, необхідно збільшити кількість пожежно-рятувальних підрозділів і вдосконалити нормативну базу щодо оптимального визначення місць їх розташування, що дозволить досягти зменшення часу прибуття пожежно-рятувальних підрозділів до місця виклику та пришвидшити початок надання допомоги постраждалим на пожежах. Для визначення кількості та типу основних i спеціальних пожежних автомобілів критерій «кількість жителів населеного пункту» необхідно доповнити характеристикою району виїзду (забезпеченість вододжерелами, умови проїзду, висота забудови, техногенна та пожежна небезпека території тощо).

2. 3 метою мінімізації наслідків пожеж в Україні, зокрема зменшення кількості загиблих, унаслідок пожеж, людей, необхідно внести зміни до [4] щодо зменшення критерію нормативу прибуття державних пожежно-рятувальних підрозділів (частин) до місця виклику у сільській місцевості з 20 хв на 10 хв.

3. Для покращення системи реагування на небезпечні події, пов'язані з пожежами, зокрема у сільській місцевості, необхідно підвищити рівень підготовки та технічної оснащеності добровільної пожежної охорони та розробити механізм іiі мотивації, тобто необхідно врегульовувати зазначені питання на законодавчому рівні.

4. Такий нормативний показник як «радіус обслуговування» не враховує планувальні, топографічні характеристики населеного пункту, стан доріг, пори року, інтенсивність руху, стан протипожежної техніки, наявність інженерних споруд тощо. 3 урахуванням наведених особливостей районів виїзду, запропоновано визначити конфігурацію району виїзду у вигляді несиметричної форми, а також визначити граничні відстані слідування за обраним напрямом і площу обслуговування індивідуально для кожного пожежно-рятувального підрозділу, що дасть змогу відображати реальний стан щодо зони обслуговування та визначати необхідну кількість і місця розташування пожежних депо.

У цілому ж, основним показником ефективності роботи пожежно-рятувальних підрозділів слід приймати не кількість фактів реагування на небезпечні події, пов'язані 3 пожежами, а кількість загиблих на них людей і час, витрачений на їх ліквідацію.

Висновки. За результатами аналітичних досліджень джерел науково-технічної інформації щодо реагування на небезпечні події, пов'язані 3 пожежами, аналізу статистичних даних Міжнародної асоціації пожежно-рятувальних служб (CTIF), вивчення закордонного досвіду щодо підходів до дислокації та кількості сил реагування на небезпечні події, пов'язані 3 пожежами, визначено основні критерії оцінювання ефективності захисту населення від небезпечних подій, а саме: збереження життя людей; час прибуття до місця пожежі; час ліквідації пожежі; збереження матеріальних цінностей.

Дослідження статистичних даних за останні десять років щодо показників реагування на небезпечні події, пов'язані з пожежами, вказують, що прийняті на території держави критерії утворення державних пожежно-рятувальних підрозділів реалізуються не в повній мірі, що підтверджується наступним:

- усереднена питома вага пожеж, на які прибували пожежно-рятувальні підрозділи упродовж нормованого часу прибуття, в містах становить 59,0\% від їх загальної кількості, а у сільській місцевості - близько 49,0\%;

- усереднена питома вага загиблих унаслідок пожеж, на які перший пожежнорятувальний підрозділ прибував у нормований час, у містах становить близько 50,0\% від їх загальної кількості, а у сільській місцевості близько $29,0 \%$;

- усереднена питома вага травмованих на пожежах, на які перший пожежно-рятувальний підрозділ прибував у нормований час, у містах становить близько 56,0\% від їх загальної кількості, а у сільській місцевості - близько $36,0 \%$;

- усереднена питома вага врятованих на пожежах, на які перший пожежно-рятувальний підрозділ прибував у нормований час, у містах становить близько 75,0\% від їх загальної кількості, а у сільській місцевості - близько $54,0 \%$.

Відносний показник кількості загиблих людей на 100 пожеж за часом прибуття першого підрозділу до місця пожежі зростає до 42 хвилин розвитку пожежі, після чого залишається незмінним.

За результатами проведених досліджень було надано пропозиції щодо удосконалення системи реагування на небезпечні події, пов'язані 3 пожежами. 


\section{СПИСОК ЛІТЕРАТУРИ}

1. Кодекс цивільного захисту України від 02 жовтня 2012 року № 5403-VI (Відомості Верховної Ради України (BВP), 2013 p., № 34-35, ст. 458).

2. Постанова Кабінету Міністрів України «Про затвердження Порядку обліку пожеж та їх наслідків» від 26 грудня 2003 року № 2030 (Офіційний вісник України, 2003 р., № 52, ст. 2802).

3. Наказ ДСНС України «Про забезпечення ведення обліку пожеж та їх наслідків» від 16 вересня 2017 року № 445.

4. Постанова Кабінету Міністрів України від 27 листопада 2013 року № 874 «Про затвердження критеріїв утворення державних пожежно-рятувальних підрозділів (частин) Оперативно-рятувальної служби цивільного захисту в адміністративно-територіальних одиницях та переліку суб'єктів господарювання, де утворюються такі підрозділи (частини)» (Офіційний вісник України, 2013 р., № 96, ст. 3555).

5. N.N. Brushlinsky, V. Ahrens, S.V. Sokolov, P. Wagner. World Fire Statistics - International Assosiation of Fire and Rescue Services (CTIF) Report. - № $23-2018$. - 62 p.

6. А. В. Красавин «Нормативное время прибытия пожарных к месту вызова. Реальность или миф?» Пожаровзрывобезопасность, 2010, том 19, №3 С. 3-6.

7. А. В. Матюшин, Нго Куанг Тоан. «Определение скорости следования пожарных подразделений к месту пожара в городе. Интернет-журнал «Технологии техносферной безопасности» (http://ipb.mos.ru/ttb) Выпуск № 3 (61), 2015 г, С. 1-6.

\section{REFERENCES}

1. Kodeks tsyvilnoho zakhystu Ukrainy vid 02 zhovtnia 2012 roku № 5403-VI (Vidomosti Verkhovnoi Rady Ukrainy (VVR), 2013 r., № 34-35, st. 458).

2. Postanova Kabinetu Ministriv Ukrainy «Pro zatverdzhennia Poriadku obliku pozhezh ta yikh naslidkiv» vid 26 hrudnia 2003 roku № 2030 (Ofitsiinyi visnyk Ukrainy, 2003 r., № 52, st. 2802).

3. Nakaz DSNS Ukrainy «Pro zabezpechennia vedennia obliku pozhezh ta yikh naslidkiv» vid 16 veresnia 2017 roku № 445.

4. Postanova Kabinetu Ministriv Ukrainy vid 27 lystopada 2013 roku № 874 «Pro zatverdzhennia kryteriiv utvorennia derzhavnykh pozhezhno-riatuvalnykh pidrozdiliv (chastyn) Operatyvno-riatuvalnoi sluzhby tsyvilnoho zakhystu v administratyvno-terytorialnykh odynytsiakh ta pereliku subiektiv hospodariuvannia, de utvoriuiutsia taki pidrozdily (chastyny)» (Ofitsiinyi visnyk Ukrainy, 2013 r., № 96, st. 3555).

5. N.N. Brushlinsky, V. Ahrens, S.V. Sokolov, P. Wagner. World Fire Statistics - International Assosiation of Fire and Rescue Services (CTIF) Report. - № 23-2018. - 62 p.

6. Krasavin A. V. (2010) Normativnoe vremya pribytiya pozharnykh k mestu vyzova. Real'nost' ili mif? [Specified time of arrival of firefighters to the place of call. Reality or myth?]. Pozharovzryvobezopasnost, vol 19, no.3, pp 3-6. (in Russian)

7. Matyushin A. V., Ngo Kuang Toan (2015) Opredelenie skorosti sledovaniya pozharnykh podrazdeleniy $\mathrm{k}$ mestu pozhara $\mathrm{v}$ gorode [Determination of fire units speed to the place of fire in the city]. Internet-zhurnal «Tekhnologii tekhnosfernoy bezopasnosti, vol. 3 (61), pp.1-6, available at: http://ipb.mos.ru/ttb. (in Russian)

8. Tytarenko A. V.(2015) Analiz chynnykiv, yaki vplyvaiut na chas prybuttia operatyvno-riatuvalnykh pidrozdiliv na
8. А. В. Титаренко. Аналіз чинників, які впливають на час прибуття оперативно-рятувальних підрозділів на виклик. // Науковий вісник: № 2 (32), 2015 p, УкрНДІПБ, м. Київ, С. 32-39.

9. Д. Ю. Белюченко, В. М. Стрілець Особливості оперативних розгортань на пожежних автоцистернах різного класу // Сучасний стан цивільного захисту України та перспективи розвитку: Матеріали 20 Всеукраїнської науково-практичної конференції, м. Київ, 9-10 жовтня. 2018 р. - Київ: Видавничий дім «Гельветика» С. 37-38.

10. Д. П. Войтович, канд. техн. наук. Підвищення рівня підготовки керівного складу підрозділів оперативнорятувальної служби на основі аналізу дій за призначенням. // Науковий вісник: № 2 (28), 2013 р., УкрНДІПБ, м. Київ, С. 115-121.

11. Н.Н.Брушлинський, Ю. М. Глуховенко, Е. А. Клепко, В. Б. Коробко. О методе упрвления СОПБ городских муниципальных образований на основе оценок пожарных рисков. // Тринадцатая научно-техническая конференция «Системы безопасности» - СБ-2004, С. 11-14

12. Методические рекомендации по определению мест размещения подразделений пожарной охраны в населенных пунктах в целях доведения времени прибытия первого подразделения пожарной охраны до нормативных значений // Утв. Главным Государственным инспектором РФ по пожарному надзору 30 декабря 2009 г. № 2-4-60-14-18. М, 2009. 25 с.

vyklyk [Factors analysis which have an influence to the arrival time of operational-rescue unit on the call]. Naukovyi visnyk UkrNDIPB, vol. 2 (32) Kyiv, pp. 32-39. (in Ukrainian)

9. D. Yu. Beliuchenko, V. M. Strilets (2018) Osoblyvosti operatyvnykh rozghortan na pozhezhnykh avtotsysternakh riznoho klasu [Features of operational deployments on fire tanks of different classes]. Proceedings of the «Suchasnyi stan tsyvilnoho zakhystu Ukrainy ta perspektyvy rozvytku: Materialy 20 Vseukrainskoi naukovo-praktychnoi konferentsii», Kyiv, Vydavnychyi dim «Helvetyka», pp. 37-38. (in Ukrainian)

10. D. P. Voitovych (2013) Pidvyshchennia rivnia pidhotovky kerivnoho skladu pidrozdiliv operatyvno-riatuvalnoi sluzhby na osnovi analizu dii za pryznachenniam [Ways of improve the preparation of management staff units]. Naukovyi visnyk UkrNDIPB, vol 2 (28), Kyiv, pp. 115121. (in Ukrainian)

11. N. N. Brushlins'kiy, Yu. M. Glukhovenko, E. A. Klepko, V. B. Korobko (2004) O metode uprvleniya SOPB gorodskikh munitsipal'nykh obrazovaniy na osnove otsenok pozharnykh riskov [On the method of SOPB managing of urban municipalities based on fire risk assessments]. Proceedings of the «Trinadtsataya nauchno-tekhnicheskaya konferentsiya «Sistemy bezopasnosti», SB, pp. 11-14 (in Russian)

12. Metodicheskie rekomendatsii po opredeleniyu mest razmeshcheniya podrazdeleniy pozharnoy okhranyv naselennykh punktakh $\mathrm{v}$ tselyakh dovedeniya vremeni pribytiya pervogo podrazdeleniya pozharnoy okhrany do normativnykh znacheniy. Utv. Glavnym Gosudarstvennym inspektorom RF po pozharnomu nadzoru 30 dekabrya 2009 g. № 2-4-60-14-18. M, 2009. $25 \mathrm{~s}$ 


\title{
RESULTS OF ANALYSIS OF THE MAIN INDICATORS OF FIRE STATISTICS IN UKRAINE WITH REGARD TO THE TIME OF ARRIVAL OF THE FIRST FIRE-FIGHTING UNITS
}

\author{
R. Klymas, A. Odynets, D. Matviichuk, L. Neseniuk
}

The Ukrainian Civil Protection Research Institute, Ukraine

\section{KEYWORDS}

statistical accounting of fires, analytical materials, condition with fires, number of fires, the number of deaths from fires, number of injured in fires, number of rescued from fires, normative time of arrival to the place of fire, time of arrival to the place of fire, absolute indicators, relative indicators, fire and rescue units, dynamics of the total number, dynamics of specific gravity.

\begin{abstract}
ANNOTATION
According to the results of the analysis of scientific and technical information, the main criteria for assessing the effectiveness of protecting the population from dangerous phenomena are identified, namely: saving people's lives; arrival time to the place of fire; time of fire elimination; the preservation of material values. According to CTIF, a comparison has been made of the existing number of Ukrainian fire services with some developed countries of the European Union, and its shortcomings have been identified. The basic indicators of fire statistics at the standard time of arrival of the first fire-fighting unit to the place of call in Ukraine as a whole and in urban and rural settlements of Ukraine in the long-term period are analyzed. The dynamics of the specific gravity of the number of fires, the number of deaths due to fires, the number of injured in the fires and the number of rescued in the fires, in the standard time of arrival of fire and rescue units for the fire were determined. The average time of arrival of the first fire and rescue unit to the place of call in Ukraine, in cities and villages in the long-term period is determined. The dynamics of the average number of fires and deaths as a result of fires on the time of arrival of the first fire and rescue unit on the fire was analyzed. According to the results of the researches, proposals were made to improve the system of responding to dangerous events related to fires in Ukraine. The relative indicator of the number of deaths per 100 fires to the number of fires has been analyzed, with the time of arrival of the first unit to the fire for 2008-2017. According to research results, conclusions are drawn.
\end{abstract}

\section{РЕЗУЛЬТАТЫ АНАЛИЗА ОСНОВНЫХ ПОКАЗАТЕЛЕЙ СТАТИСТИКИ ПОЖАРОВ В УКРАИНЕ ПО ОТНОШЕНИЮ К ВРЕМЕНИ ПРИБЫТИЯ ПЕРВОГО ПОДРАЗДЕЛЕНИЯ ПОЖАРНОЙ ОХРАНЫ}

Р.В. Климась, А.В. Одинец, Д.Я. Матвийчук, Л.П. Несенюк

Украинский научно-исследовательский институт гражданской защиты, Украина

\section{КЛЮЧЕВЫЕ СЛОВА}

статистический учет пожаров, аналитические материалы, состояние с пожарами, количество пожаров, количество погибших в результате пожаров, количество травмированных на пожарах, количество спасенных на пожарах, нормативное время прибытия к месту пожара, время прибытия к месту пожара, абсолютные показатели, относительные показатели, пожарно-спасательные подразделения, динамика общего количества, динамика удельного веса.

\begin{abstract}
АННОТАЦИЯ
Проанализированы основные показатели статистики пожаров в Украине, как в целом, так и в городах и сельской местности Украины отдельно, за нормативным временем прибытия первого подразделения пожарной охраны к месту вызова за долгосрочный период.
\end{abstract}

